\title{
Crystal Structure and Pseudo-Mackay Clusters of R-AIPdCo
}

\author{
Rayko Simura*, Shota Suzuki, Kunio Yubuta and Kazumasa Sugiyama \\ Institute for Materials Research, Tohoku University, Sendai 980-8577, Japan
}

\begin{abstract}
The structure of the rhombohedral $(R-)$ AlPdCo phase was determined by single-crystal X-ray diffraction: space group $R \overline{3}$ (No. 148$)$, $a=2.91019(8) \mathrm{nm}$ and $c=1.31854(4) \mathrm{nm}, V=9.6709(5) \mathrm{nm}^{3}$, atoms/cell $=660, F(000)=12820, R=0.0481$ for the observed 3354 reflections measured by Mo $K \alpha$ radiation $(\lambda=0.071069 \mathrm{~nm}) . R$-AlPdCo has two types of pseudo-Mackay clusters (pMCs) around Co(12) at $18 f$ and $\mathrm{Al} / \mathrm{Pd}(14)$ at $3 a$. The first shell of $\mathrm{Co}(12)$-pMC consists of nine $\mathrm{Al}$ sites. The second shell of the Co(12)-pMC is a combination of (M, Co)icosahedron (ICO) and Al-icosidodecahedron (IDO), where M is a mixed site of Pd, Co or Al. On the other hand, the first shell of the other pMC around $\mathrm{Al} / \mathrm{Pd}(14)$ consists of two sub-shells: an M-cube and Al-octahedron. The outer shell of the Al/Pd(14)-pMC consists of an M-ICO and Al-IDO. These pMCs interpenetrate each other by sharing the edges of the second ICO shells and their interstitial space is filled by Al-ICOs around $\mathrm{M}(1)$ and $\mathrm{M}(2)$. These structural features suggest that the structure of $R$-AlPdCo is realized by linking the $\mathrm{Co}(12)-$ and $\mathrm{Al} / \mathrm{Pd}(14)$-pMCs together with two types of smaller Al-ICO around the M(1) and M(2) sites. [doi:10.2320/matertrans.M2013058]
\end{abstract}

(Received February 12, 2013; Accepted May 7, 2013; Published June 14, 2013)

Keywords: X-ray diffraction, crystal structure, approximants, AlPdCo, pseudo-Mackay cluster, rhombohedral

\section{Introduction}

Structural information on approximant phases is critical to understand the atomic structure of quasi-crystalline phases. ${ }^{1)}$ An Al-Pd-Co alloy system is an aluminumtransition metal ternary system that is expected to have quasi-crystalline phases and related approximants. ${ }^{2)}$ Previous studies clarified the complicated phase diagram in the $\mathrm{Al}-$ $\mathrm{Pd}-\mathrm{Co}$ system and reported a variety of crystalline phases of $\mathrm{W}, \mathrm{V}, \mathrm{U}, \mathrm{F}, \mathrm{C}_{2}, \mathrm{Y}_{2}, \varepsilon_{16}, \varepsilon_{22}$ and $\varepsilon_{34} \cdot{ }^{3-7)} \mathrm{A}$ series of $\varepsilon$ phases is found in alloy systems of Al-Pd, Al-Pd-Fe, Al-Pd-Co and so on. Their structures are closely associated with that of the $\mathrm{Al}_{3} \mathrm{Pd}$ phase (binary $\varepsilon_{6}$-phase), which is an important crystalline approximant for decagonal quasicrystals with a period of $1.6 \mathrm{~nm}$. ${ }^{7}$ The $\mathrm{W}$ phase with $4-5 \%$ of $\mathrm{Pd}$ showed cell parameters similar to those of $\mathrm{W}-\mathrm{AlCoNi}{ }^{8}{ }^{8}$ This suggests that structural information for the $\mathrm{W}-\mathrm{AlCoPd}$ phase is useful for understanding the atom clusters in the decagonal phase with a periodicity of $0.8 \mathrm{~nm}$. There are also several cubic phases with a cell parameter of about $1.5 \mathrm{~nm}$ in the $\mathrm{Al}-\mathrm{Pd}-\mathrm{Ru}, \mathrm{Al}-\mathrm{Pd}-\mathrm{Fe}$ and $\mathrm{Al}-\mathrm{Cu}-\mathrm{Ru}-\mathrm{Si}$ systems, ${ }^{9,10)}$ whose structures are expected to be closely related to that of $\mathrm{C}_{2}-$ AlPdCo. In addition, the orthorhombic phase reported by Grin et al. ${ }^{11)}$ showed the similar cell parameters with $\mathrm{Y}_{2}$ AlPdCo. These facts clearly suggest that a series of structural investigations in the ternary Al-Pd-Co system will help to understand the columnar structures with a variety of periods together with the atom clusters with local icosahedral symmetry.

During our structural investigation of the compositional space near the $\varepsilon_{16}$ phase in the Al-Pd-Co system, we found a new crystalline phase (hereafter $R$-AlPdCo) with pseudoMackay clusters without geometrical disorder. This paper reports the single-crystal X-ray diffraction results for the $R$ AlPdCo phase and discusses the unique pseudo-Mackay icosahedral clusters together with their spatial distribution in a unit cell.

*Corresponding author, E-mail: ray@imr.tohoku.ac.jp

\section{Experimental Procedure}

\subsection{Sample preparation}

Alloy ingots with nominal compositions of $\mathrm{Al}_{72} \mathrm{Pd}_{18} \mathrm{Co}_{10}$ (\#1) and $\mathrm{Al}_{74} \mathrm{Pd}_{14} \mathrm{Co}_{12}$ (\#2) were prepared from $\mathrm{Al}$ (99.999\%), Pd (>99.95\%) and Co $(99.9 \%)$ by using a conventional arc melting furnace and purified Ar atmosphere. Each as-prepared ingot was crushed, placed in a carbon crucible and then annealed in a vacuum furnace. Sample \#1 was heated at $1000^{\circ} \mathrm{C}$ and subsequently cooled to $900^{\circ} \mathrm{C}$ for $22 \mathrm{~h}\left(\sim 4.5^{\circ} \mathrm{C} /\right.$ hour $)$. Sample \#2 was heated at $1050^{\circ} \mathrm{C}$ and slowly cooled to $790^{\circ} \mathrm{C}$ for $65 \mathrm{~h}\left(\sim 4^{\circ} \mathrm{C} /\right.$ hour $)$.

\subsection{Compositional characterization}

The morphology of the as-prepared ingots was observed by using a Hitachi S-3400N scanning electron microscope (SEM). In the as-prepared sample \#1, the aggregates of crystals with rhombic morphology were frequently observed, as shown in Fig. 1. This suggested the presence of a rhombohedral $(R-)$ phase, which was not previously known to exist in the Al-Pd-Co system. ${ }^{5)}$ Furthermore, electron probe microanalysis (EPMA) using a JEOL JXA-8621MX microanalyser indicated that the chemical composition of the $R$-phase in the as-prepared sample \#1 was $\mathrm{Al}_{72-73^{-}}$ $\mathrm{Pd}_{15-20} \mathrm{Co}_{7-13}$. The $\mathrm{Al}$ content was constant in every grain of the $R$-phase; however, the Pd content decreased from the rim to centre of the crystalline grains at the expense of the Co content. After annealing of the as-prepared ingot \#1, the $\varepsilon$-phases replaced the $R$-phase as the main constituents. This strongly suggests that the $R$-phase is the first phase to form from the high-temperature liquid and its stable chemical compositional region is different from the nominal composition of \#1. Fortunately, a chemically homogeneous specimen of the $R$-phase with the chemical composition of $\mathrm{Al}_{72-74} \mathrm{Pd}_{13-14} \mathrm{Co}_{13-14}$ was found in the annealed sample \#2.

\subsection{X-ray diffraction}

A $200 \times 150 \times 80 \mu \mathrm{m}^{3}$ single-crystal was cut from the annealed sample \#2 and used in the single-crystal X-ray diffraction study. The intensity data of 29579 reflections were 


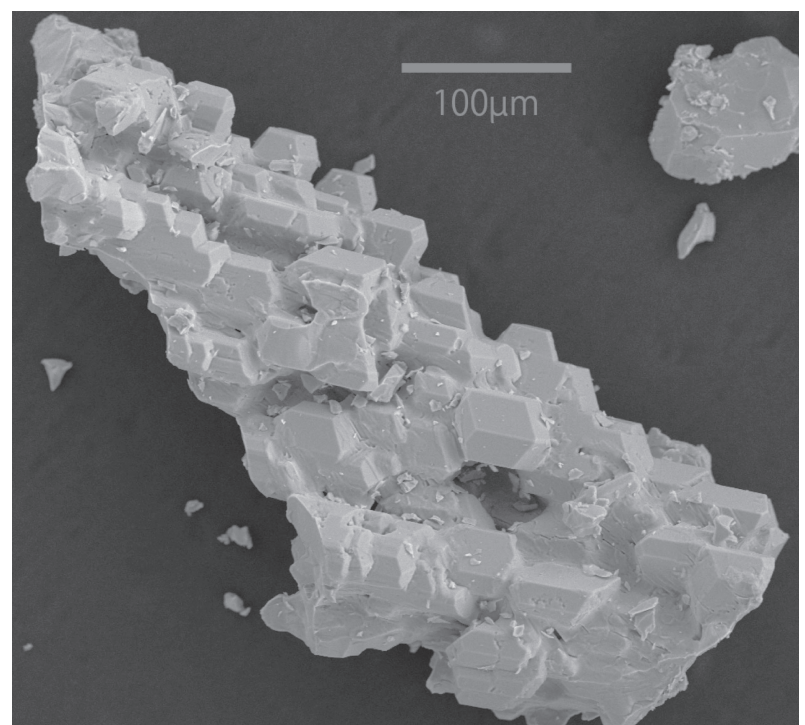

Fig. 1 SEM photograph of the aggregate of $R$-AlPdCo single crystals in the as-prepared sample \#1. Note the rhombohedral shape of the crystals.

collected using a Rigaku R-AXIS RAPID ${ }^{12)}$ and Mo $K \alpha$ radiation. After Lorentz and polarization corrections, an absorption correction $\left(\mathrm{ABSCOR}^{13)}\right)$ was performed by considering the shape of the single-crystal specimen. The refined cell constants allowed us to select a hexagonal lattice with $a=2.91019(8) \mathrm{nm}$ and $c=1.31854(4) \mathrm{nm}$. The systematic reflection condition, $-h+k+l=3 n$, together with the intensity distribution led us to consider the space group $R \overline{3}$. Data reduction according to this space group yielded 4922 independent reflections. Among the reflections, 3354 reflections met the condition $F_{0}>4.0 \sigma\left(F_{0}\right)$. The experimental conditions are summarized in Table 1.

\section{Results and Discussions}

\subsection{Results of structural analysis}

The initial structural model for the $R$-AlPdCo phase was obtained by direct methods. ${ }^{14)}$ The obtained structural model yielded 39 independent sites and a total of 660 atoms in the unit cell. 13 sites were occupied by heavy metals such as $\mathrm{Pd}$ or $\mathrm{Co}$ and the other 26 sites by Al. Each heavy metal site was surrounded by Al sites. This feature is common in Al-based approximant structures in the binary Al-Co and Al-Pd systems. ${ }^{11,15)}$ The calculation of inter-atomic distances allowed us to classify the heavy metal sites into two groups. The three $\operatorname{Co}(11), \operatorname{Co}(12)$ and $\operatorname{Co}(13)$ sites were ranked in the first group with the nearest-neighbour distances from 0.228 to $0.232 \mathrm{~nm}$ (see Fig. 2). These shorter distances correspond to that of the typical $\mathrm{Co}-\mathrm{Al}$ pair; ${ }^{11)}$ thus, the three sites $(\mathrm{Co}(11)$, $\operatorname{Co}(12)$ and $\operatorname{Co}(13)$ ) were considered to be fully occupied by Co. The nearest-neighbour distances of the other 10 heavy metal sites range from 0.245 to $0.264 \mathrm{~nm}$ and they appear to be occupied by Pd.

After several iterations of least-squares calculations using the software SHELXL-97, ${ }^{16)}$ the converged displacement parameters for the Pd sites remained extraordinary large. This result clearly suggests that a chemically disordered model should be used for the Pd sites. The chemical composition
Table 1 Summary of measurements.

\begin{tabular}{|c|c|}
\hline Composition (EPMA) & $\mathrm{Al}_{73} \mathrm{Pd}_{13.5} \mathrm{Co}_{13.5}$ \\
\hline Space group & $R \overline{3}$ \\
\hline$a(\mathrm{~nm})$ & $2.91019(8)$ \\
\hline$c(\mathrm{~nm})$ & $1.31854(4)$ \\
\hline$V\left(\mathrm{~nm}^{3}\right)$ & $9.6709(5)$ \\
\hline Density $\left(\mathrm{Mg} \mathrm{m}^{-3}\right)$ & 4.784 \\
\hline Absorption coefficient $\left(\mathrm{mm}^{-1}\right)$ & 8.855 \\
\hline Crystal dimensions (mm) & $0.15 \times 0.20 \times 0.08$ \\
\hline Radiation & Mo $K a$ \\
\hline Number of measured reflections & 29579 \\
\hline Number of independent reflections & 4922 \\
\hline $\begin{array}{l}\text { Number of observed refractions } \\
\qquad\left(F_{0}>4.0 \sigma\left(F_{0}\right)\right)\end{array}$ & 3354 \\
\hline$R_{\text {int }}$ & 0.0657 \\
\hline \multirow[t]{2}{*}{$R_{\text {sig }}$} & 0.0557 \\
\hline & $-37<h<37$ \\
\hline \multirow[t]{2}{*}{ Index range } & $-37<k<35$ \\
\hline & $-17<l<17$ \\
\hline $2 \theta_{\min }, 2 \theta_{\max }$ & $6.38,54.96$ \\
\hline Number of parameters & 347 \\
\hline$w R_{\mathrm{all}}\left(F^{2}\right)$ & 0.1300 \\
\hline$R_{\mathrm{gt}}(F)$ & 0.0481 \\
\hline Goodness of fit, $S$ & 1.050 \\
\hline Extinction coefficient & $0.000089(6)$ \\
\hline Weighing scheme & $\begin{array}{c}w=1 /\left[\sigma^{2}\left(F_{0}\right)+(0.0696 P)^{2}\right] \\
\text { where } P=\left(F_{0}^{2}+2 F_{\mathrm{c}}^{2}\right) / 3\end{array}$ \\
\hline $\begin{array}{l}\text { Largest diff. peak and hole } \\
\quad\left(\text { electrons } / \mathrm{nm}^{3}\right)\end{array}$ & $2.70 \times 10^{-3},-1.61 \times 10^{-3}$ \\
\hline
\end{tabular}

of the first structural model $\mathrm{Al}_{68.2} \mathrm{Pd}_{23.6} \mathrm{Co}_{8.2}(\mathrm{Al}: \mathrm{Pd}: \mathrm{Co}=$ $450: 156: 54$ in a unit cell) also supported the notion that greater amounts of $\mathrm{Al}$ and $\mathrm{Co}$ should be considered in the structural model. The observed compositional variation in the $R$-phase, discussed in the experimental section, supports the substitution of $\mathrm{Co}$ at the Pd sites. However, ordinary single-crystal X-ray diffraction cannot specify the chemical composition of the heavy metal sites because their occupancies depend on combinations of $\mathrm{Pd}, \mathrm{Co}$ and $\mathrm{Al}$. Therefore, we continued the least-squares calculations by introducing ten $\mathrm{Pd} / \mathrm{Al}$ mixed sites (hereafter $\mathrm{M}$ sites) at the expense of $\mathrm{Pd}$ sites. Chemical disorder was also introduced in the $\mathrm{Al} / \mathrm{Pd}(14)$ site because the displacement parameter became slightly negative when full occupancy by Al was considered. The refinement with anisotropic displacement parameters together with the extinction correction parameter of the SHELXL software $(\chi=0.000089(6))$ converged at $R=0.0481$ for the observed 3354 reflections. The maximum and minimum residual electron densities were 2.70 and $-1.61 \times 10^{-3}$ $\mathrm{e} / \mathrm{nm}^{3}$, respectively. The final atomic coordinates and anisotropic atomic displacement parameters are listed in Tables 2 and 3. The chemical composition of the converged structural model yielded $\mathrm{Al}_{75.5} \mathrm{Pd}_{16.3} \mathrm{Co}_{8.2}$. The difference in the chemical composition of the structural model suggests that considerable amount of Co resides in the $\mathrm{M}$ sites at the expense of $\mathrm{Pd}$ and $\mathrm{Al}$. The larger atomic displacement parameters for several $\mathrm{Al}$ sites will be discussed in the next section. The calculated inter-atomic distances around the 

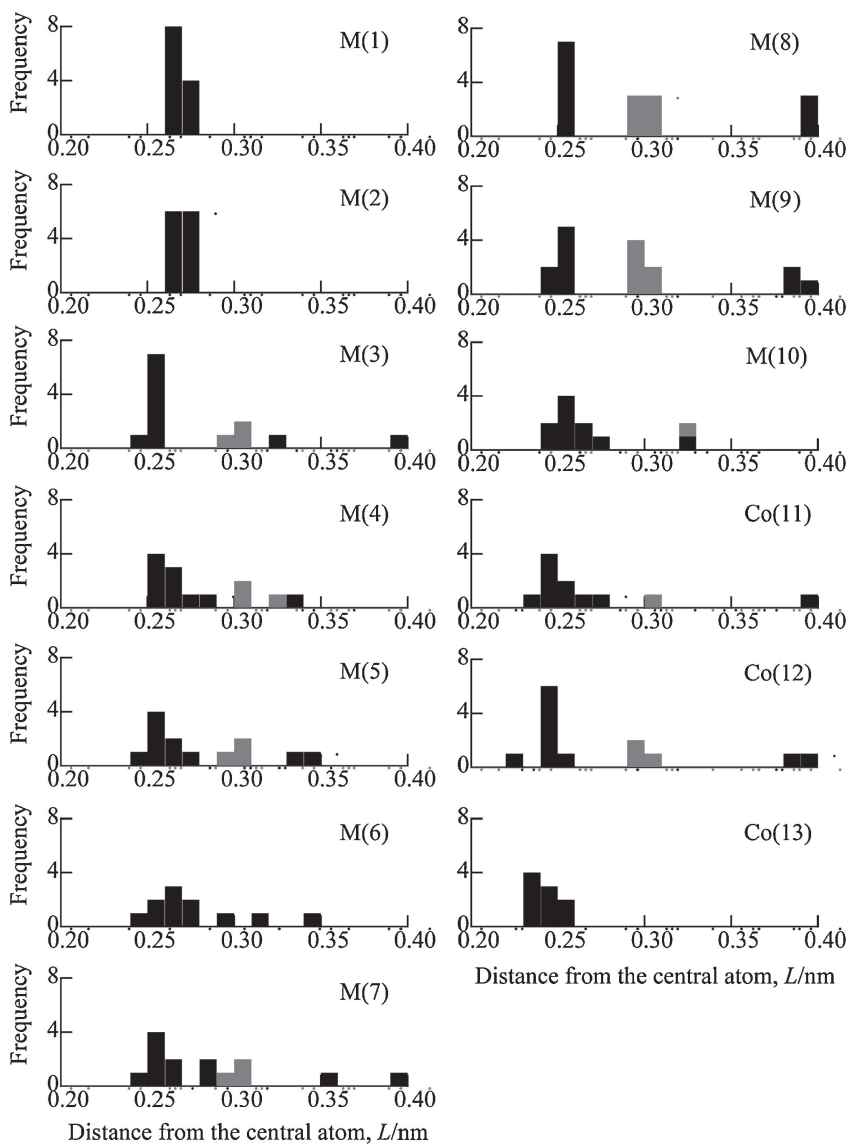

Distance from the central atom, $L / \mathrm{nm}$

Fig. 2 Inter-atomic distances from the central atoms for the heavy metal sites (i.e., the $\mathrm{M}(1-10)$ and $\mathrm{Co}(11-13)$ sites) are shown as histograms. The black bars indicate the Al sites and the grey bars show the sites of the heavy metals. Note that the Al coordination polyhedrons around $\mathrm{M}(1)$ and $\mathrm{M}(2)$ are icosahedrons (ICOs). heavy metal sites (i.e., $\mathrm{M}(1-10)$ and $\mathrm{Co}(11-13))$ are shown as histograms in Fig. 2.

\subsection{Discussion on site occupancy of the heavy metal sites}

Among the mixed heavy metal sites ( $M$ sites), the $M(1)$ and $\mathrm{M}(2)$ sites have icosahedrally coordinated Al sites with average distances of about $0.269 \mathrm{~nm}$. This distance is much longer than that for the typical $\mathrm{Co}-\mathrm{Al}$ pair. This geometrical feature allows us to conclude that the $\mathrm{M}(1)$ and $\mathrm{M}(2)$ sites are mainly occupied by $\mathrm{Pd}$ and $\mathrm{Al}$ with larger atomic radius. On the other hand, the heavy metal sites of $\mathrm{M}(4)-\mathrm{M}(7)$ and $\mathrm{M}(10)$ indicate a rather scattered distribution of inter-atomic distances with the nearest-neighbour distances from 0.245 to $0.253 \mathrm{~nm}$. Although the refined Pd contents for these sites suggested a preference for $\mathrm{Pd}$, the appearance of shorter distances implies that these sites should be considered as mixed sites of $\mathrm{Co}, \mathrm{Pd}$ and $\mathrm{Al}$. The histograms for the remaining $\mathrm{M}(3)$ and $\mathrm{M}(8)-\mathrm{M}(9)$ sites show an apparent maximum gap at $0.26-0.29 \mathrm{~nm}$. The features of these three sites correspond to the Co sites. Among them, the M(8) and $\mathrm{M}(9)$ sites indicate the site-scattering value of 31.8 and 25.7, respectively. These lower values suggest a preference for $\mathrm{Al}$ at these sites. The remaining $\mathrm{M}(3)$ site has larger sitescattering values $(\sim 40.2)$, suggesting that the site is mainly shared by $\mathrm{Co}$ and $\mathrm{Pd}$.

\subsection{Discussion on structural features of $\boldsymbol{R}$-AIPdCo}

By searching the coordination atoms within $0.6 \mathrm{~nm}$ from every central atom, two types of pseudo-Mackay clusters (pMCs) can be distinguished around $\mathrm{Co}(12)$ and $\mathrm{Al} / \mathrm{Pd}(14)$.

Figure 3 shows one type of the pMC around $\mathrm{Co}(12)$ at $18 f$. The Co(12)-pMC consists of 51 atoms arranged in two shells. [i]
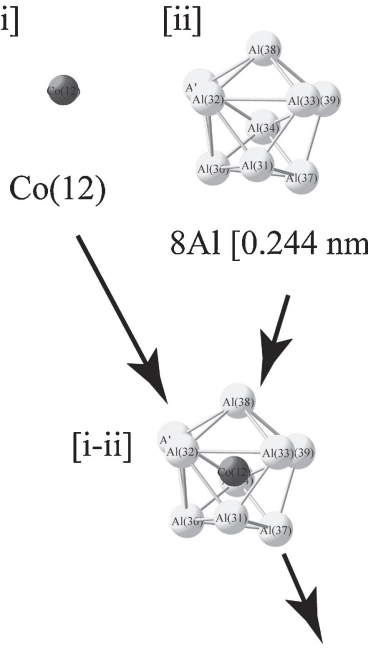

[i-ii-iii-iv] [iii]

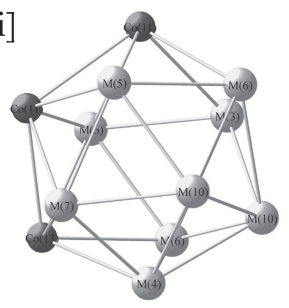

$12(\mathrm{M}, \mathrm{Co})[0.439 \mathrm{~nm}]$ [iv]

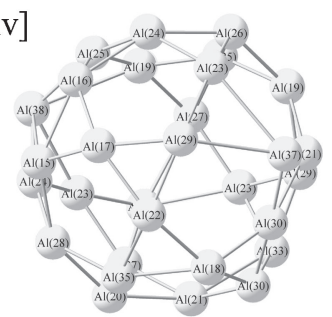

$30 \mathrm{Al}[0.481 \mathrm{~nm}]$

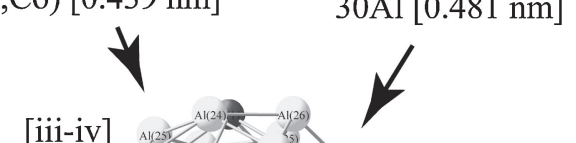

Fig. 3 Components of the pseudo-Mackay cluster (pMC) around the Co(12) site [i-ii-iii-iv] are illustrated. The Co(12)-pMC can be divided into four components [i]-[iv]. The value in the parentheses is the averaged distance of the constituent atoms from the central atom in the $\operatorname{Co}(12)-\mathrm{pMC}$. 
Table 2 Atomic parameters of $R$-AlPdCo.

\begin{tabular}{|c|c|c|c|c|c|c|c|}
\hline Atom & Site & Site-scattering value ${ }^{* *}$ & Occupancy* & $x$ & $y$ & $z$ & $U_{\text {eq. }}\left(\times 10^{2} \mathrm{~nm}^{2}\right)$ \\
\hline $\mathrm{M}(1)$ & $18 f$ & 42.9 & $0.817(5) / 0.183$ & $0.22360(3)$ & $0.20208(3)$ & $0.16833(6)$ & $0.0096(3)$ \\
\hline $\mathrm{M}(2)$ & $3 b$ & 42.0 & $0.77(2) / 0.24$ & 0 & 0 & $1 / 2$ & $0.0090(6)$ \\
\hline $\mathrm{M}(4)$ & $18 f$ & 43.8 & $0.847(5) / 0.153$ & $0.07024(3)$ & $0.11107(3)$ & $0.27388(6)$ & $0.0141(3)$ \\
\hline $\mathrm{M}(5)$ & $18 f$ & 42.0 & $0.805(5) / 0.195$ & $0.31576(3)$ & $0.13995(3)$ & $0.27121(6)$ & $0.0114(3)$ \\
\hline $\mathrm{M}(6)$ & $18 f$ & 40.9 & $0.768(5) / 0.232$ & $0.19219(3)$ & $0.27573(3)$ & $0.40089(7)$ & $0.0103(3)$ \\
\hline$M(7)$ & $18 f$ & 41.1 & $0.775(5) / 0.225$ & $0.17022(3)$ & $0.04725(3)$ & $0.07939(7)$ & $0.0127(3)$ \\
\hline $\mathrm{M}(8)$ & $6 c$ & 31.8 & $0.522(7) / 0.478$ & 0 & 0 & $0.1933(2)$ & $0.0108(6)$ \\
\hline $\mathrm{M}(9)$ & $18 f$ & 25.7 & $0.346(5) / 0.654$ & $0.08650(5)$ & $0.07767(5)$ & $0.0656(2)$ & $0.0101(4)$ \\
\hline $\mathrm{M}(10)$ & $18 f$ & 33.8 & $0.567(4) / 0.433$ & $0.15384(4)$ & $0.09336(4)$ & $0.40073(8)$ & $0.0127(3)$ \\
\hline $\operatorname{Co}(11)$ & $18 f$ & 27 & 1 & $0.30128(4)$ & $0.00918(4)$ & $0.07649(9)$ & $0.0056(3)$ \\
\hline $\operatorname{Co}(12)$ & $18 f$ & 27 & 1 & $0.02467(4)$ & $0.22617(4)$ & $0.33586(9)$ & $0.0082(3)$ \\
\hline $\operatorname{Co}(13)$ & $18 f$ & 27 & 1 & $0.12795(4)$ & $0.25387(4)$ & $0.06130(9)$ & $0.0053(3)$ \\
\hline $\operatorname{Al}(15)$ & $18 f$ & 13 & 1 & $0.2055(2)$ & $0.2459(2)$ & $0.0055(2)$ & $0.0099(6)$ \\
\hline $\operatorname{Al}(16)$ & $18 f$ & 13 & 1 & $0.3434(2)$ & $0.1035(2)$ & $0.1270(2)$ & $0.0114(6)$ \\
\hline $\operatorname{Al}(17)$ & $18 f$ & 13 & 1 & $0.2547(2)$ & $0.1311(2)$ & $0.1265(2)$ & $0.0126(6)$ \\
\hline $\operatorname{Al}(18)$ & $18 f$ & 13 & 1 & $0.0633(2)$ & $0.0219(2)$ & $0.3425(2)$ & $0.0131(6)$ \\
\hline $\operatorname{Al}(19)$ & $18 f$ & 13 & 1 & $0.3951(2)$ & $0.0632(2)$ & $0.0115(2)$ & $0.0126(6)$ \\
\hline $\operatorname{Al}(20)$ & $18 f$ & 13 & 1 & $0.1234(2)$ & $0.1716(2)$ & $0.1229(2)$ & $0.0144(6)$ \\
\hline $\operatorname{Al}(21)$ & $18 f$ & 13 & 1 & $0.1627(2)$ & $0.1822(2)$ & $0.3335(2)$ & $0.0149(6)$ \\
\hline $\operatorname{Al}(22)$ & $18 f$ & 13 & 1 & $0.1519(2)$ & $0.1014(2)$ & $0.2092(2)$ & $0.0136(6)$ \\
\hline $\operatorname{Al}(23)$ & $18 f$ & 13 & 1 & $0.15610(2)$ & $0.3433(2)$ & $0.1268(2)$ & $0.0146(6)$ \\
\hline $\operatorname{Al}(24)$ & $18 f$ & 13 & 1 & $0.0649(2)$ & $0.2826(2)$ & $0.0039(2)$ & $0.0148(6)$ \\
\hline $\operatorname{Al}(25)$ & $18 f$ & 13 & 1 & $0.2979(2)$ & $0.3046(2)$ & $0.1214(2)$ & $0.0148(6)$ \\
\hline $\mathrm{Al}(26)$ & $18 f$ & 13 & 1 & $0.0504(2)$ & $0.3077(2)$ & $0.2218(2)$ & $0.0179(7)$ \\
\hline $\operatorname{Al}(27)$ & $18 f$ & 13 & 1 & $0.1916(2)$ & $0.2718(2)$ & $0.2039(2)$ & $0.0158(6)$ \\
\hline $\operatorname{Al}(29)$ & $18 f$ & 13 & 1 & $0.2413(2)$ & $0.1538(2)$ & $0.3278(2)$ & $0.0178(7)$ \\
\hline $\operatorname{Al}(30)$ & $18 f$ & 13 & 1 & $0.0795(2)$ & $0.1036(2)$ & $0.4711(2)$ & $0.0175(6)$ \\
\hline $\operatorname{Al}(31)$ & $18 f$ & 13 & 1 & $0.1458(2)$ & $0.01110(2)$ & $0.2838(3)$ & $0.0294(8)$ \\
\hline $\operatorname{Al}(32)$ & $18 f$ & 13 & 1 & $0.2449(2)$ & $0.0383(2)$ & $0.2030(3)$ & $0.0330(9)$ \\
\hline $\operatorname{Al}(33)$ & $18 f$ & 13 & 1 & $0.2177(2)$ & $0.0595(2)$ & $0.4322(3)$ & $0.0310(2)$ \\
\hline $\operatorname{Al}(34)$ & $18 f$ & 13 & 1 & $0.1144(2)$ & $0.2998(2)$ & $0.3655(4)$ & $0.047(2)$ \\
\hline $\operatorname{Al}(35)$ & $18 f$ & 13 & 1 & $0.0099(2)$ & $0.0856(2)$ & $0.1238(3)$ & $0.042(2)$ \\
\hline $\operatorname{Al}(36)$ & $18 f$ & 13 & 1 & $0.0726(2)$ & $0.22110(2)$ & $0.1982(3)$ & $0.046(2)$ \\
\hline $\operatorname{Al}(37)$ & $18 f$ & 13 & 1 & $0.0777(2)$ & $0.1912(2)$ & $0.4126(3)$ & $0.044(2)$ \\
\hline $\operatorname{Al}(38)$ & $18 f$ & 13 & 1 & $0.2919(2)$ & $0.0237(2)$ & $0.3828(4)$ & $0.055(2)$ \\
\hline $\operatorname{Al}(39)$ & $18 f$ & 13 & 1 & $0.2409(3)$ & $0.2079(2)$ & $0.4894(4)$ & $0.077(2)$ \\
\hline
\end{tabular}

${ }^{*}$ The $\mathrm{M}$ sites are the mixed sites and their occupancies were refined by the Pd/Al-mixed-site model (see text).

${ }^{* *}$ The values for the column of site-scattering value were calculated from the occupancies and the atomic number (electron number) of Pd and Al.

The first shell is an irregularly shaped polyhedron of nine $\mathrm{Al}$ sites around the $\mathrm{Co}(12)$ centre, as shown in Fig. 3[i-ii]. In $R$ AlPdCo, the Al sites with relatively larger atomic displacement parameters occupy the sites in the first shell of the two types of pMCs in $R$-AlPdCo. Eight out of nine Al sites of the first shell in $\mathrm{Co}(12)$-pMC come into this type of $\mathrm{Al}$ sites (Al(31)-Al(34), $\mathrm{Al}(36)-\mathrm{Al}(39))$. The longest axes of the anisotropic displacement ellipsoids are perpendicular to the radial direction of the $\operatorname{Co}(12)$-pMC, suggesting that the displacement of the $\mathrm{Al}$ atoms occurs while keeping their atomic distances up to the central atom. In nine $\mathrm{Al}$ sites of the first shell, five sites (Al(26), $\mathrm{Al}(33), \mathrm{Al}(34), \mathrm{Al}(37)$ and $\mathrm{Al}(38)$ ) make up the vertices of the outer shell (Alicosidodecahedrons (IDOs)) of the neighbouring $\mathrm{Co}(12)$ pMCs. The $\mathrm{Al}(31)$ site is the vertex of another $\mathrm{pMC}$ around
$\mathrm{Al} / \mathrm{Pd}(14)$. The rest of the sites $(\mathrm{Al}(32), \mathrm{Al}(36)$ and $\mathrm{Al}(39))$ are present only in the first shell of $\mathrm{Co}(12)$-pMC. The second shell has a radius of about $0.469 \mathrm{~nm}$ (Fig. 3[iii-iv]) and may be divided into two sub-shells. One is an icosahedron (ICO) consisting of seven mixed heavy metal $\mathrm{M}$ sites and five Co sites (Fig. 3[iii]) and each vertex of the ICO is capped by five Al sites to form the Al-IDO, which is the other sub-shell (Fig. 3[iv]).

The structure for another type of pMC around $\mathrm{Al} / \mathrm{Pd}(14)$ located at $3 a$ is shown in Fig. 4. The size of the $\mathrm{Al} / \mathrm{Pd}(14)-$ $\mathrm{pMC}$ is $0.482 \mathrm{~nm}$ and is larger than the $\mathrm{Co}(12)-\mathrm{pMC}$ $(0.469 \mathrm{~nm})$. The first shell of the $\mathrm{Al} / \mathrm{Pd}(14)-\mathrm{pMC}$ may be divided into two sub-shells (Fig. 4[ii-iii]). One is a cube of two $M(8)$ sites and six $M(9)$ sites (Fig. 4[ii]) and the other is an octahedron (OCT) of six $\mathrm{Al}(35)$ sites (Fig. 4[iii]). The 
Table 3 Anisotropic parameters $\left(\times 10^{2} \mathrm{~nm}^{2}\right)$ of $R$-AlPdCo.

\begin{tabular}{|c|c|c|c|c|c|c|}
\hline Atom & $U_{11}$ & $U_{22}$ & $U_{33}$ & $U_{23}$ & $U_{13}$ & $U_{12}$ \\
\hline $\mathrm{M}(1)$ & $0.0116(4)$ & $0.0109(4)$ & $0.0074(4)$ & $0.0001(3)$ & $0.0002(3)$ & $0.0064(3)$ \\
\hline $\mathrm{M}(2)$ & $0.0098(8)$ & $U_{11}$ & $0.008(2)$ & 0 & 0 & $0.0049(4)$ \\
\hline $\mathrm{M}(4)$ & $0.0105(4)$ & $0.0177(5)$ & $0.0124(5)$ & $0.0067(3)$ & $0.0028(3)$ & $0.0058(3)$ \\
\hline $\mathrm{M}(5)$ & $0.0132(4)$ & $0.0172(5)$ & $0.0068(5)$ & $-0.0013(3)$ & $-0.0012(3)$ & $0.0098(4)$ \\
\hline $\mathrm{M}(6)$ & $0.0123(5)$ & $0.0108(5)$ & $0.0078(5)$ & $-0.0019(3)$ & $0.0009(3)$ & $0.0059(3)$ \\
\hline$M(7)$ & $0.0150(5)$ & $0.0095(4)$ & $0.0115(5)$ & $-0.0010(3)$ & $0.0041(3)$ & $0.0046(4)$ \\
\hline $\mathrm{M}(8)$ & $0.0125(7)$ & $U_{11}$ & $0.008(2)$ & 0 & 0 & $0.0063(4)$ \\
\hline $\mathrm{M}(9)$ & $0.0105(7)$ & $0.0109(7)$ & $0.0082(7)$ & $-0.0006(5)$ & $-0.0009(5)$ & $0.0048(6)$ \\
\hline $\mathrm{M}(10)$ & $0.0119(6)$ & $0.0149(6)$ & $0.0112(6)$ & $0.0033(4)$ & $0.0021(4)$ & $0.0066(4)$ \\
\hline $\operatorname{Co}(11)$ & $0.0054(5)$ & $0.0060(5)$ & $0.0034(6)$ & $0.0000(4)$ & $-0.0016(4)$ & $0.0013(4)$ \\
\hline $\operatorname{Co}(12)$ & $0.0088(6)$ & $0.0091(6)$ & $0.0063(6)$ & $-0.0004(5)$ & $0.0001(5)$ & $0.0041(5)$ \\
\hline $\operatorname{Co}(13)$ & $0.0075(6)$ & $0.0052(5)$ & $0.0040(6)$ & $-0.0018(4)$ & $-0.0033(4)$ & $0.0037(4)$ \\
\hline $\operatorname{Al}(15)$ & $0.011(2)$ & $0.012(2)$ & $0.009(2)$ & $0.001(2)$ & $-0.001(2)$ & $0.006(2)$ \\
\hline $\operatorname{Al}(16)$ & $0.014(2)$ & $0.013(2)$ & $0.0010(2)$ & $-0.001(2)$ & $0.001(2)$ & $0.007(2)$ \\
\hline $\operatorname{Al}(17)$ & $0.014(2)$ & $0.014(2)$ & $0.0010(2)$ & $-0.001(2)$ & $0.001(2)$ & $0.006(2)$ \\
\hline $\operatorname{Al}(18)$ & $0.015(2)$ & $0.015(2)$ & $0.011(2)$ & $-0.003(2)$ & $-0.001(2)$ & $0.008(2)$ \\
\hline $\operatorname{Al}(19)$ & $0.013(2)$ & $0.017(2)$ & $0.011(2)$ & $-0.001(2)$ & $0.001(2)$ & $0.009(2)$ \\
\hline $\operatorname{Al}(20)$ & $0.016(2)$ & $0.016(2)$ & $0.014(2)$ & $0.004(2)$ & $0.002(2)$ & $0.009(2)$ \\
\hline $\operatorname{Al}(21)$ & $0.016(2)$ & $0.015(2)$ & $0.015(2)$ & $-0.002(2)$ & $0.003(2)$ & $0.008(2)$ \\
\hline $\operatorname{Al}(22)$ & $0.019(2)$ & $0.015(2)$ & $0.009(2)$ & $0.001(2)$ & $0.001(2)$ & $0.0010(2)$ \\
\hline $\operatorname{Al}(23)$ & $0.021(2)$ & $0.016(2)$ & $0.0010(2)$ & $-0.002(2)$ & $-0.001(2)$ & $0.0010(2)$ \\
\hline $\mathrm{Al}(24)$ & $0.0010(2)$ & $0.019(2)$ & $0.017(2)$ & $-0.001(2)$ & $0.002(2)$ & $0.008(2)$ \\
\hline $\operatorname{Al}(25)$ & $0.014(2)$ & $0.019(2)$ & $0.013(2)$ & $0.003(2)$ & $-0.001(2)$ & $0.009(2)$ \\
\hline $\operatorname{Al}(26)$ & $0.019(2)$ & $0.014(2)$ & $0.021(2)$ & $0.002(2)$ & $-0.008(2)$ & $0.007(2)$ \\
\hline $\operatorname{Al}(29)$ & $0.013(2)$ & $0.021(2)$ & $0.017(2)$ & $0.001(2)$ & $0.001(2)$ & $0.006(2)$ \\
\hline $\operatorname{Al}(30)$ & $0.023(2)$ & $0.019(2)$ & $0.014(2)$ & $0.004(2)$ & $0.006(2)$ & $0.013(2)$ \\
\hline $\operatorname{Al}(31)$ & $0.026(2)$ & $0.035(2)$ & $0.037(2)$ & $0.008(2)$ & $0.005(2)$ & $0.022(2)$ \\
\hline $\operatorname{Al}(32)$ & $0.039(2)$ & $0.035(2)$ & $0.030(2)$ & $0.016(2)$ & $0.016(2)$ & $0.022(2)$ \\
\hline $\operatorname{Al}(33)$ & $0.040(2)$ & $0.032(2)$ & $0.056(3)$ & $-0.021(2)$ & $-0.020(2)$ & $0.025(2)$ \\
\hline $\operatorname{Al}(34)$ & $0.040(2)$ & $0.017(2)$ & $0.062(3)$ & $0.008(2)$ & $-0.037(2)$ & $-0.001(2)$ \\
\hline $\operatorname{Al}(35)$ & $0.041(2)$ & $0.045(2)$ & $0.041(2)$ & $0.003(2)$ & $-0.002(2)$ & $0.024(2)$ \\
\hline $\operatorname{Al}(36)$ & $0.061(3)$ & $0.050(2)$ & $0.034(2)$ & $0.011(2)$ & $0.028(2)$ & $0.034(2)$ \\
\hline $\operatorname{Al}(37)$ & $0.056(3)$ & $0.043(2)$ & $0.045(3)$ & $0.005(2)$ & $-0.014(2)$ & $0.035(2)$ \\
\hline $\mathrm{Al}(38)$ & $0.023(2)$ & $0.080(3)$ & $0.052(3)$ & $-0.026(2)$ & $-0.008(2)$ & $0.019(2)$ \\
\hline $\operatorname{Al}(39)$ & $0.150(5)$ & $0.084(4)$ & $0.024(3)$ & $0.016(2)$ & $0.035(3)$ & $0.079(4)$ \\
\hline
\end{tabular}

*The $\mathrm{M}$ sites are the mixed sites. See text.

local atomic arrangements of the first shell are quite similar to those found in ordinary $\mathrm{BCC}$ structures. The $\mathrm{Al}(35)$ site of Al-OCT is also one of the $\mathrm{Al}$ sites with the larger atomic displacement parameters shown previously. The anisotropic displacement ellipsoid of $\mathrm{Al}(35)$ has an almost spherical shape; however, the major axis of the ellipsoid is parallel to the radial direction, suggesting a stable BCC structure for the first shell. $\mathrm{Al}(35)$ is the vertex in the AlIDO of the second shell in the neighbouring $\operatorname{Co}(12)-p M C$. The second shell of this cluster is also divided into two sub-shells (Fig. 4[iv-v]). One is an ICO produced by twelve $\mathrm{M}$ sites (Fig. 4[iv]) and the other is Al-IDO (Fig. 4[v]). Each vertex of the ICO is capped by five $\mathrm{Al}$ sites to form the Al-IDO.

In the two types of pMCs described, the second shell structure suitably reproduces the atomic feature in the arrangement of the typical Mackay clusters that have local icosahedral symmetry. The icosahedral symmetry is broken in the first shell of the Mackay clusters. The first shell consists of nine $\mathrm{Al}$ sites around the Co centre, which is also observed around a $\mathrm{Co}$ atom in $\mathrm{Al}_{13} \mathrm{Co}_{4}$ alloy. ${ }^{11)}$ In addition, the irregularly shaped polyhedron of the first shell of pMC is observed in the structural model of $\chi$-AlPdRe. ${ }^{17}$ )

Considering the whole structure of the $R$-phase, most of the $\mathrm{M}$ and Co sites are the vertex sites of the second shell ((M, Co)-ICOs) in the pMCs (Fig. 3[iii] and Fig. 4[iv]); however, the $\mathrm{M}(1)$ and $\mathrm{M}(2)$ sites are not shared by the vertex site of the pMC. These two sites are located in the interstitial space of the network of the pMCs connection. As schematically shown in Fig. 5(a), the vertices of $\mathrm{Al}$ sites in the IDO of $\mathrm{Co}(12)-$ and $\mathrm{Al} / \mathrm{Pd}(14)-\mathrm{pMCs}$ interpenetrate each other. The ICO of the second shell in the 


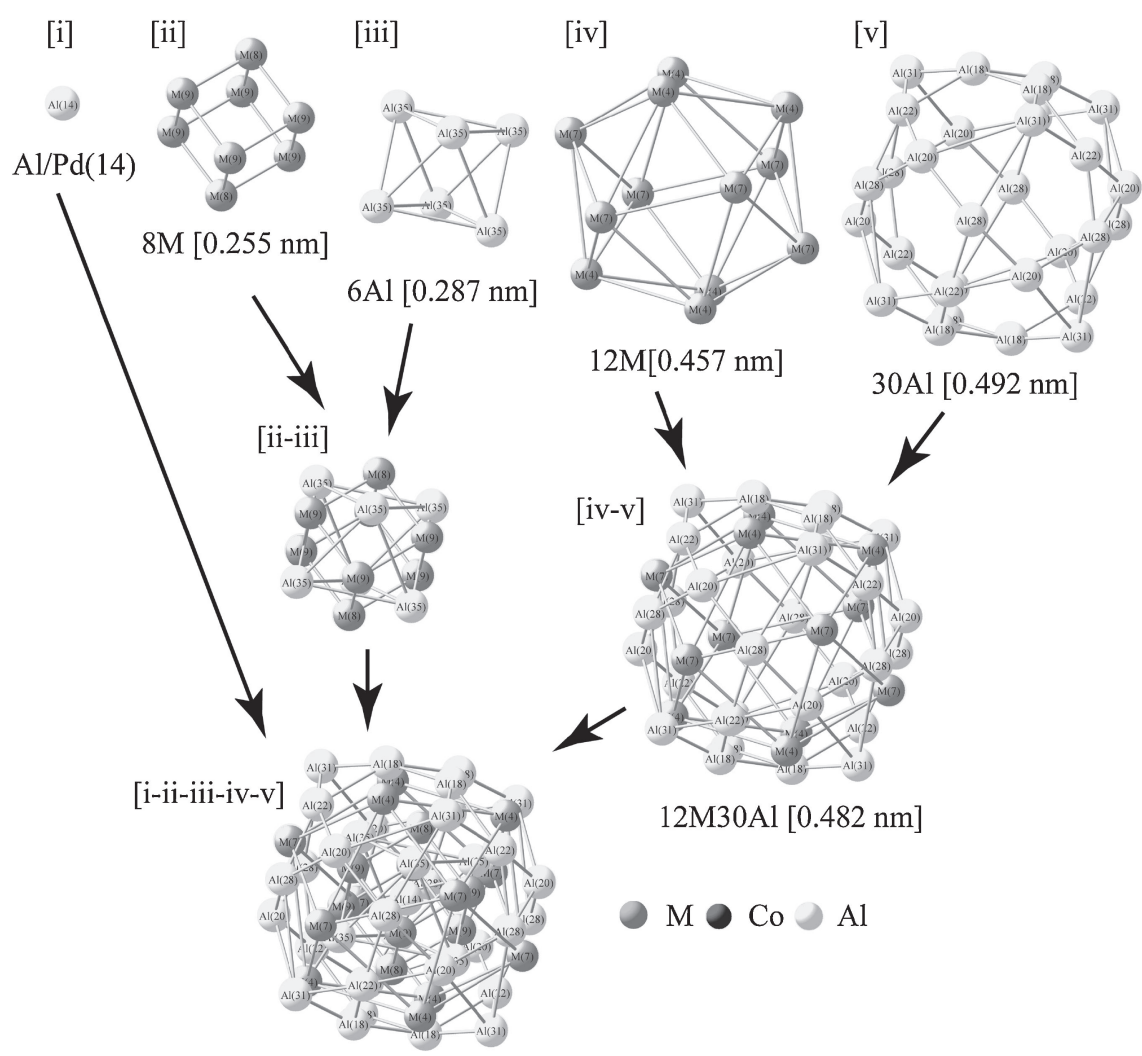

Fig. 4 Components of the pseudo-Mackay cluster (pMC) around the $\mathrm{Al} / \mathrm{Pd}(14)$ site [i-ii-iii-iv-v] are illustrated. The Al/Pd(14)-pMC can be divided into five components [i]-[v]. The value in the parentheses is the averaged distance of the constituent atoms from the central atom in the $\mathrm{Al} / \mathrm{Pd}(14)-\mathrm{pMC}$.

pMCs touch each other by sharing their edges (Fig. 5(b)) and the interstitial space among the pMCs is occupied by M(1)- and M(2)-ICOs. Focusing on the environment of the connection around a $\mathrm{pMC}$, the $\mathrm{Co}(12)-\mathrm{pMC}$ is surrounded by five $\mathrm{Co}(12)-\mathrm{pMCs}$, one $\mathrm{Al} / \mathrm{Pd}(14)-\mathrm{pMC}$, one $\mathrm{M}(1)-\mathrm{ICO}$ and six $\mathrm{M}(2)-\mathrm{ICOs}$ (Fig. 5(c)); the $\mathrm{Al} / \mathrm{Pd}(14)-\mathrm{pMC}$ is surrounded by six Co(12)-pMCs, two M(1)-ICOs and six $\mathrm{M}(2)$-ICOs (Fig. 5(d)). By maintaining this relation in the connections, $3 \mathrm{Al} / \mathrm{Pd}(14)$-pMCs, $18 \mathrm{Co}(12)$-pMCs, $18 \mathrm{M}(1)-$ ICOs and $3 \mathrm{M}(2)-\mathrm{ICO}$ are distributed in a unit cell (Fig. 5(e)).

\section{Conclusion}

We found a new crystalline $R$-AlPdCo phase in the Al-PdCo system. The structure contains two types of pMCs around the $\mathrm{Co}(12)$ and $\mathrm{Al} / \mathrm{Pd}(14)$ sites. The first shell of the $\mathrm{Co}(12)-$ pMC consists of nine Al. The second shell of the $\operatorname{Co}(12)-$ pMC consists of a (M, Co)-ICO and Al-IDO, where $\mathrm{M}$ is a mixed site of $\mathrm{Pd}, \mathrm{Co}$ or $\mathrm{Al}$. On the other hand, the first shell of the other pMC around $\mathrm{Al} / \mathrm{Pd}(14)$ consists of two sub-shells: a M-cube and an Al-octahedron. The outer shell of this $\mathrm{Al} / \mathrm{Pd}(14)-\mathrm{pMC}$ consists of a M-ICO and an Al-IDO. These pMCs interpenetrate each other by sharing the edges of the second (M, Co)-ICO shells and their interstitial space is subsequently filled by an Al-ICOs around the $\mathrm{M}(1)$ and $\mathrm{M}(2)$ sites. These structural features suggest that the structure of $R$-AlPdCo is realized by linking the $\mathrm{Co}(12)$ - and $\mathrm{Al} /$ $\mathrm{Pd}(14)$-pMCs together with two types of smaller Al-ICO around the $\mathrm{M}(1)$ and $\mathrm{M}(2)$ sites.
Chemical and/or geometrical disorder of the first shell is common in pMCs. They were classified into three types in our previous study: the first shell with (1) keeping partial icosahedral symmetry, (2) having three-fold symmetry and losing the five-fold symmetry and (3) others. ${ }^{18)}$ The first shell of the $\operatorname{Co}(12)-p M C$ belongs to type (3) and is thought to be a typical example of the irregularly shaped first shell, which has a smaller central atom such as Co. On the other hand, the case of the $\mathrm{Al} / \mathrm{Pd}(14)-\mathrm{pMC}$ can be classified as type (2), which is another fundamental structure for the first shell of pMC with a larger central atom such as $\mathrm{Al}$ and $\mathrm{Pd}$. We believe that the first shell feature of the pMC, such as in $\chi$ AlPdRe, ${ }^{17)}$ can be understood by combining the two types of pMCs in $R$-AlPdCo.

In the current study, the Co occupancy in the $M$ sites was not determined because of the technical limitations of the conventional XRD system. Further examination with techniques such as anomalous X-ray scattering and/or neutron diffraction will provide useful information to understand chemical disorder in the $\mathrm{M}$ sites and discuss its influence on the pMC structure in $R$-AlPdCo.

\section{Acknowledgments}

The authors are grateful to Y. Murakami, Institute for Materials Research, for his help with EPMA. This work was supported in part by a Grant-in-Aid for Challenging Exploratory Research (22656152) from the Japan Society for the Promotion of Science (JSPS). 
(a) Connection of the outermost shells

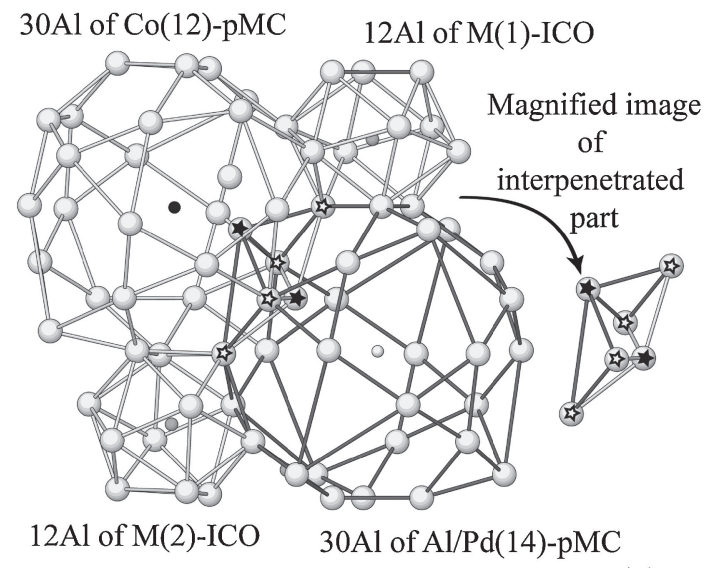

(c) around $\mathrm{Co}(12)-\mathrm{pMC}$

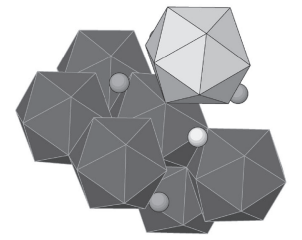

(d) around $\mathrm{Al} / \mathrm{Pd}(14)-\mathrm{pMC}$

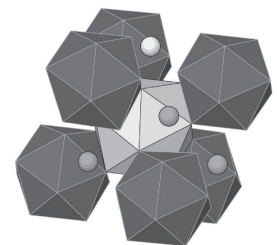

$\mathrm{Al} \bullet \mathrm{M} \bullet \mathrm{Co}$

(b) Connection of inner icosahedrons

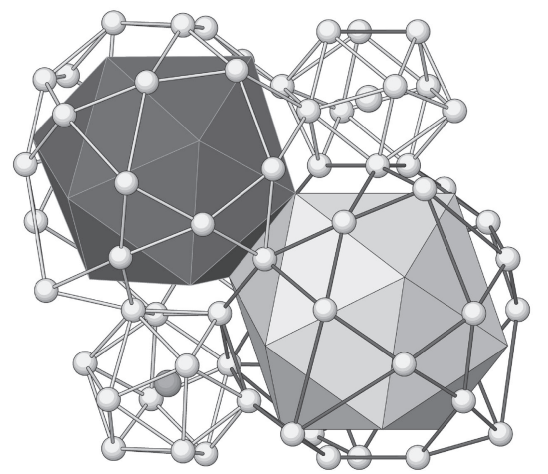

(e) Distribution of clusters in a cell

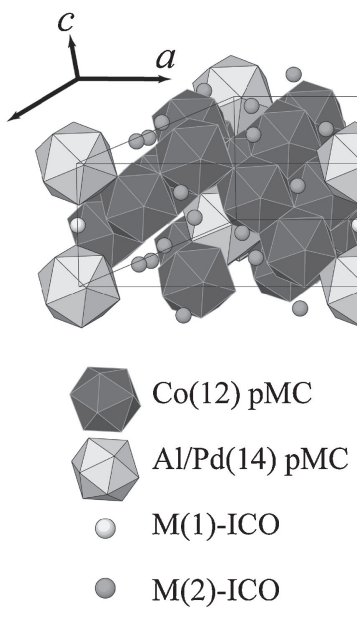

Fig. 5 Connections of $\mathrm{Co}(12)$ - and $\mathrm{Al} / \mathrm{Pd}(14)$-centred pseudo-Mackay clusters (pMCs) and M(1)- and M(2)-centred Al-icosahedrons (ICOs) are illustrated in (a). The $\mathrm{Co}(12)$ and $\mathrm{Al} / \mathrm{Pd}(14)$-icosidodecahedrons (IDOs) (i.e., Fig. 2[iv] and Fig. 3[v]) interpenetrate each other and share four vertexes (open stars). The solid stars indicate the penetrated vertexes inside the $\mathrm{Co}(12)-\mathrm{and} \mathrm{Al} / \mathrm{Pd}(14)-\mathrm{IDO}$. The $\mathrm{M}(1)$ or M(2)-ICOs fill the gap space in the IDO network by sharing faces with the IDOs. As shown in (b), the Co(12) and $\mathrm{Al} / \mathrm{Pd}(14)$ ICOs (i.e., Fig. 2[iii] and Fig. 3[iv]) are present inside the IDOs, respectively. The Co(12) and Al/Pd(14)-ICOs are connected to each other by sharing edges. The distribution of the polyhedrons around $\mathrm{Co}(12)$ are shown in (c), those around $\mathrm{Al}(14)$ in (d) and those in the unit cell in (e).

\section{REFERENCES}

1) M. I. Goldman and K. F. Kelton: Rev. Mod. Phys. 65 (1993) 213-230.

2) K. Yubuta, W. Sun and K. Hiraga: Philos. Mag. A 75 (1997) 273-284.

3) M. Yurechko and B. Grushko: Mater. Sci. Eng. 294 (2000) 139-142.

4) S. Mi, M. Yurechko, J. Wu and B. Grushko: J. Alloy. Compd. 329 (2001) L1-L4.

5) M. Yurechko, B. Grushko, T. Velikanova and K. Urban: J. Alloy. Compd. 337 (2002) 172-181.

6) M. Yurechko, B. Grushko, T. Y. Velikanova and K. Urban: J. Alloy. Compd. 367 (2004) 20-24.

7) K. Hiraga, T. Ohsuna and M. Kawasaki: J. El. M. 49 (2000) 729-733.

8) K. Sugiyama, S. Nishimura and K. Hiraga: J. Alloy. Compd. 342 (2002) 65-71.

9) K. Sugiyama, K. Hiraga and K. Saito: Mater. Sci. Eng. 294 (2000) 345347.
10) K. Sugiyama, T. Kato, K. Saito and K. Hiraga: Philos. Mag. Lett. 77 (1998) 165-171.

11) J. Grin, U. Burkhardt and M. Ellner: J. Alloy. Compd. 206 (1994) 243247.

12) RAPID-AUTO: (software): Rigaku Corporation, Tokyo, Japan (1998).

13) ABSCOR: (software): T. Higashi, Rigaku Corporation, Tokyo Japan, (1995).

14) A. Altomare, G. Cascarano, C. Giacovazzo, A. Guagliarde, M. C. Burla, G. Polidori and M. Camalli: J. Appl. Crystallogr. 32 (1999) 115119.

15) Y. Matsuo and K. Hiraga: Philos. Mag. 70 (1994) 155-161.

16) G. M. Sheldrick: Acta Crystallogr. A 64 (2008) 112-122.

17) S. Suzuki, R. Simura and K. Sugiyama: Philos. Mag. 91 (2011) 26102616.

18) S. Suzuki, R. Simura and K. Sugiyama: Key Eng. Mater. 508 (2012) 353-356. 